\begin{tabular}{ll}
\hline \hline MINING AND METALLURGY INSTITUTE BOR & ISSN: 2334-8836 \\
& UDK: 622 \\
\hline \hline
\end{tabular}

\title{
ANALYSIS THE OPERATING PARAMETERS OF БеЛАЗ TRUCK AT THE OPEN PITS OF THE BROWN COAL MINE "BANOVICI" BASED ON PROCESSOR DATA
}

\begin{abstract}
This work presents a methodology of data collecting and processing from the load and fuel control system СКЗИT, installed on БелАЗ 75131 trucks, owned by the Brown Coal Mine "Banovici“in Banovici. There is also a methodology of display the achieved operating parameters. Transport of coal and overburden is performed by these trucks. Total of eleven trucks has processors. Conclusions about working time, length of crossed routes, quantity of transported load, achieved cycles, etc. can be presented by data processing.
\end{abstract}

Keywords: open pit, БелАЗ, truck, Brown Coal Mine ”Banovici“, processor

\section{INTRODUCTION}

Production (overburden and coal) at the open pits of the Brown Coal Mine "Banovici" in Banovici, is realized by discontinuous technology with the use of classical cyclic loading-transport complex shoveltruck.

The open pit mining system is a sequence of works on excavation, transport and dumping of overburden, production and other (auxiliary) processes, which provide the designed (planned) capacity of the open pit.

At the open pits of Brown Coal Mine "Banovici" ("Grivice" and "Turija"), a longitudinal one sided mining system is applied with deepening by overlying contact of ore body (coal seam) and transport of overburden on the external dump.

Production process of overburden and coal consists of the following working processes: drilling and blasting (preparation of rock digging and loading), digging and loa- ding (excavation), transport, dumping of overburden and dumping of coal (if necessary).

After coal loading onto trucks, it is transported from the working area and unloading into the crusher. Transport of coal from the crusher to the reloading bunker at the railway station "Draganja" is carried out by conveyor belt system, and further by rail to the separation. At the open pit "Turija", transport of coal to the reloading bunker is carried out by trucks. Transport of overburden is carried out by trucks directly from the working area at the open pit to the dump.

Open pits are mutually connected by midfield transport roads used for crossing of trucks and other mechanization from one to the other open pit, and also to the service complex "Besin" due to the preventive maintenance and repair. Works on overburden is realized in a way that after drilling and blasting, the overburden is

\footnotetext{
* RGGF Tuzla B\&H
} 
loaded by shovel onto trucks. Digging and loading of overburden is performed by shovels and hydraulic shovels with the previous blasting of rock mass above shovel level. At the open pits, the overburden from benches is transported to the dumping benches by trucks via transporting roads. At dump, truck goes on dump road to the dumping bench where dumping of overburden is done. All transport roads are constructed by overburden and covered with solid and persistent marls.

\section{DATA OBTAINED FROM PROCESSOR ON БелA3 TRUCKS}

The Brown Coal Mine "Banovici" has eleven БелАЗ 75131 trucks with processors, respectively load and fuel control system СКЗиТ.

This system, except of monitoring transported load and fuel consumption, provides data on load and unload time as well as length of crossed routes for full and empty trucks.

Load and fuel control system СКЗиТ consists of the following elements: controller, panel management and indication, pressure sensors on shock absorbers, fuel level sensor in tank, inclinometer and signal of load quantity.

Figure 1 shows a module with the system panel СКЗиТ. Processor data on БелАЗ trucks are obtained in the form shown in Figure 2.

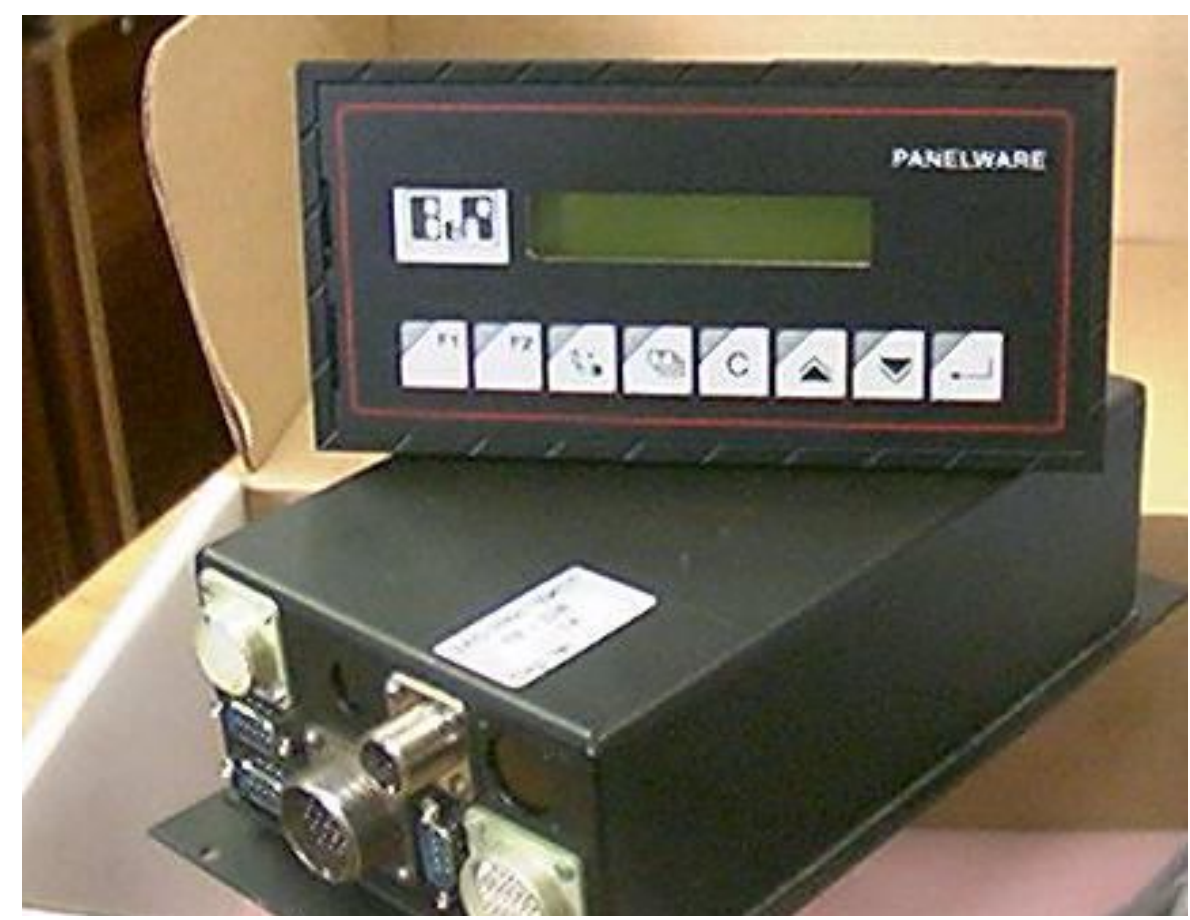

Figure 1 Load module with the panel 


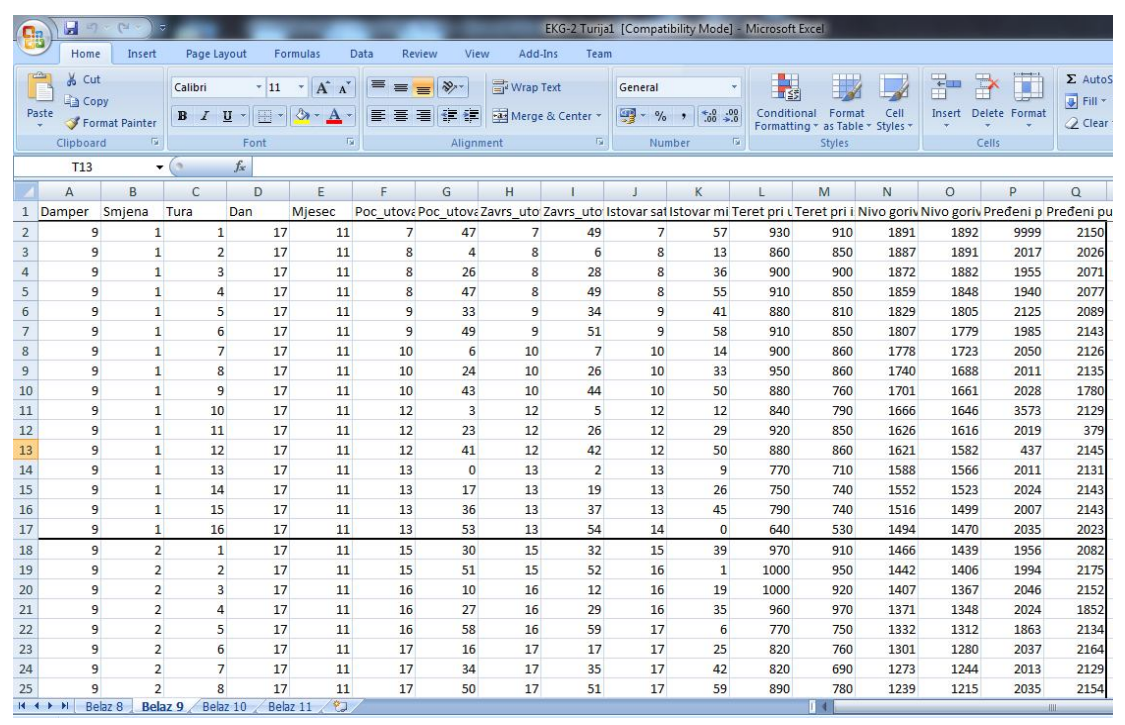

Figure 2

For one shift, about 255 data is got, which can be used for individual transformations, and later for analyses. Data from the truck processor are needed for previously preparation for analysis. Data are in such form that is necessary to do the transformation of data for time because of classification by hours and minutes in the columns (Figure 2). To present in a diagram, these data are needed to transform in the form of data TIME (0:00:00). In Microsoft Excel, it is necessary to add some new columns to get data in a form TIME (0:00:00) and time expressed in seconds. In displayed file with processors, it can be observed that the time, which shows seconds, is not recorded, in contrast with data which could be got on the basis of truck monitoring with built-in GPS receiver. Registered data are in two separate columns about mass of the load immediately after loading and at unloading, increased ten times. Mainly, the mass data of the load, immediately at the end of loading, show considerable differences in comparison with registered data at unloading. These two values are different be cause the sensor, when loading, registers higher value of load, because the load is unevenly distributed in the truck box. During the transport from the load place to the unload place, it occurs to more balanced distribution of load and then the registered load mass at the unloading is authoritative for further analysis. Data about driving time of full damper can be obtained from the subtraction registered unloading time and finished loading time. Values of crossed routes of full truck and empty truck are there in the file. If the values of length of crossed routes are divided with driving time of full truck, a driving speed of full truck can be obtained. If the difference between registered time of load beginning and time of previous unloading is defined, a driving time of empty truck can be obtained, that is longer than driving time of full truck, so it can be concluded that the speed of empty truck is low in comparison with the speed of full truck. Length of crossed routes of empty truck also have in itself the length for load maneuvering, so they are not adequate for determining the driving time of the same. 


\section{THE ACHIEVED OPERATING PARAMETERS OF THE TRUCKS \\ БелАЗ 8, БелАЗ 9, AND БелАЗ 10}

By data analyzing with processor, it is possible to show the achieved results of truck operation for each shift. Daily reports on operation of three trucks are shown in the next text.

Open pit Turija

Shovel ЭКГ 8И (2)

Truck БелАЗ 75131 (8)

Dump of the open pit Turija

\section{Daily report}

Total of transported load $3726 \mathrm{t}$

Average values of transported load 81 t per cycle

Total duration of loading (without truck changing time) $4650 \mathrm{~s}$

Average duration of loading (without truck changing time) $99.13 \mathrm{~s}$

Total fuel consumption 14081

Number of cycles (tours) 46

Total of crossed route of full truck $91720 \mathrm{~m}$

Average crossed route of full truck (semi cycle full truck) $1993.91 \mathrm{~m}$

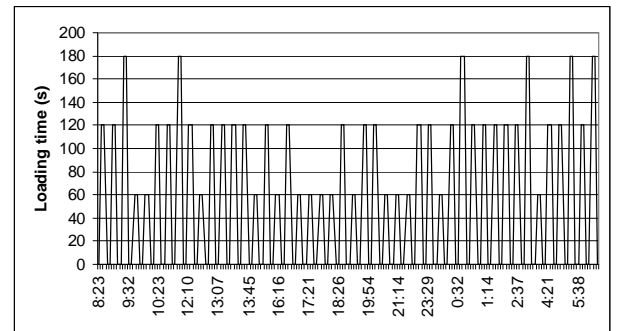

Figure 3

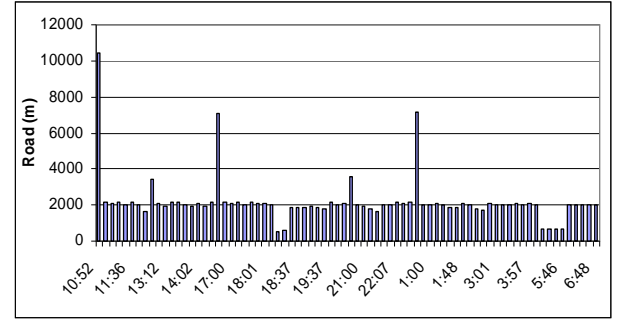

Figure 5
Total of crossed route of empty truck $101196 \mathrm{~m}$ - with coming under the shovel at the beginning of shift and coming under the shovel at the end of shift

Average crossed route of empty truck (semi cycle empty truck) $2026.6 \mathrm{~m}$

Total driving time of full truck $19920 \mathrm{~s}$

Average driving time of full truck (semi cycle full truck) $433.04 \mathrm{~s}$

Average driving speed of full truck $4.60 \mathrm{~m} / \mathrm{s}$

\section{Presentation of information in the form of graphs - truck БелАЗ 8}

Figure 3 shows a graph of duration the loading and Figure 4 mass of load transported during one cycle. Figure 5 shows a graph of crossed routes in driving of full and empty truck and Figure 6 registered speeds.

Figures 7 and 8 show a graph on changes the level of fuel during loading and unloading of truck.

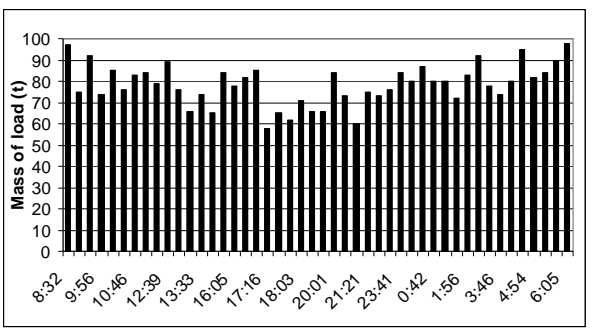

Figure 4

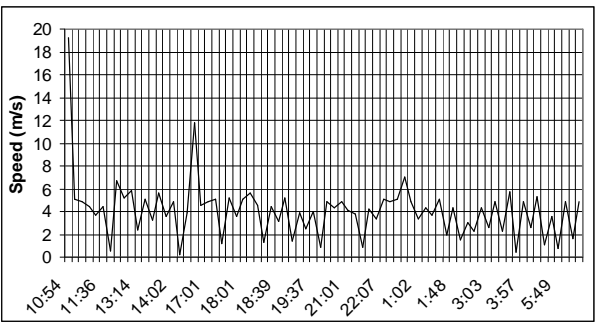

Figure 6 


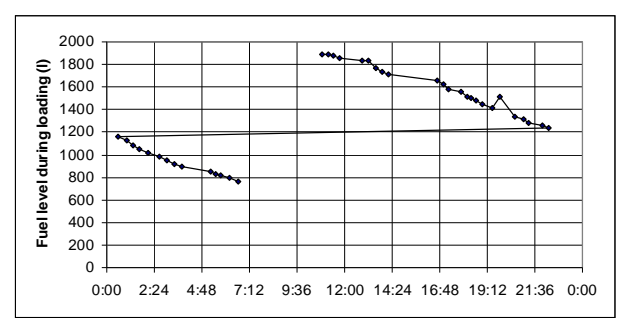

Figure 7

\section{Open pit Turija}

Shovel ЭКГ 8И (2)

Truck БелАЗ 75131 (9)

Dump of the open pit Turija

\section{Daily report}

Total of transported load $3612 \mathrm{t}$

Average values of transported load $7852 \mathrm{t}$ per cycle

Total duration of loading (without truck changing time) $4980 \mathrm{~s}$

Average duration of loading (without truck changing time) $108.26 \mathrm{~s}$

Total fuel consumption 14541

Number of cycles (tours) 46

Total of crossed route of full truck $91885 \mathrm{~m}$

Average crossed route of full truck (semi cycle full truck) $1997.50 \mathrm{~m}$

Total of crossed route of empty truck $113481 \mathrm{~m}$ - with coming under the shovel

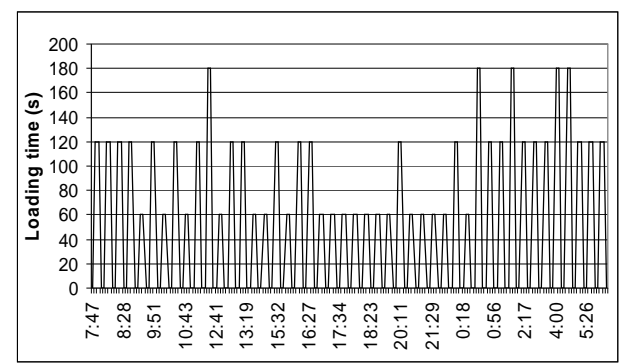

Figure 9

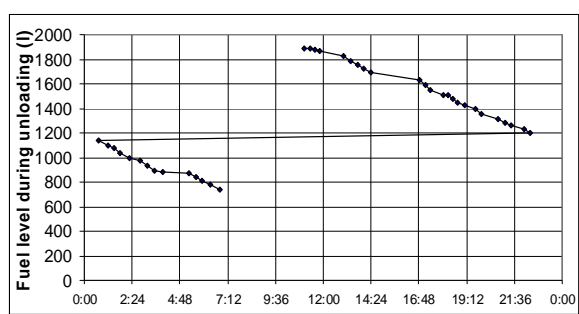

Figure 8

at the beginning of shift and coming under the shovel at the end of shift

Average crossed route of empty truck (semi cycle empty truck) $2074.21 \mathrm{~m}$

Total driving time of full truck $19860 \mathrm{~s}$

Average driving time of full truck (semi cycle full truck) $431.74 \mathrm{~s}$

Average driving speed of full truck $4.63 \mathrm{~m} / \mathrm{s}$

\section{Presentation of information in the form of graphs - truck БелАЗ 9}

Figure 9 shows a graph of duration of loading and Figure 10 mass of load transported during one cycle. Figure 11 shows a graph of crossed routes in driving of full and empty truck and Figure 12 registered speeds.

Figures 13 and 14 show a graph on changes the level of fuel during loading and unloading of truck.

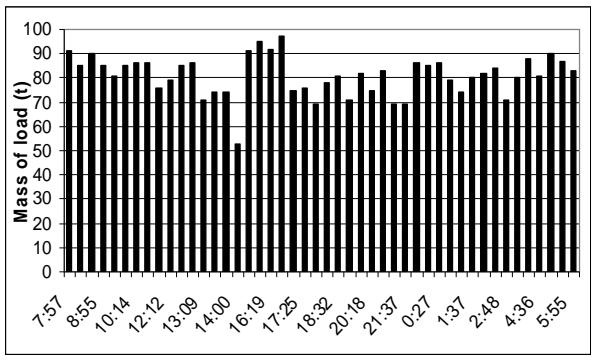

Figure 10 


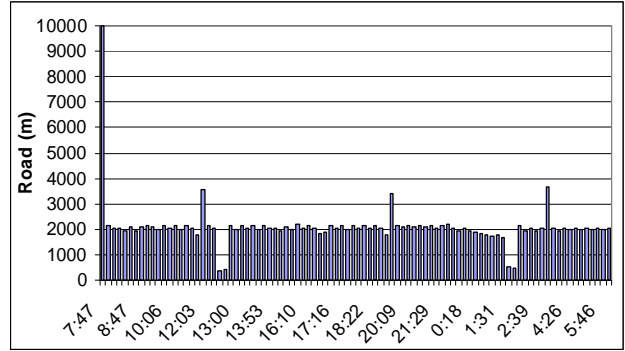

Figure 11

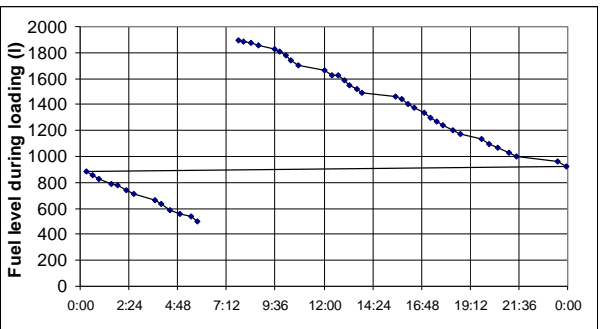

Figure 13

Open pit Turija

Shovel ЭКГ 8И (2)

Truck БелАЗ 75131 (10)

Dump of open pit Turija

\section{Daily report}

Total of transported load $2944 \mathrm{t}$

Average values of transported load

$77.47 \mathrm{t}$ per cycle

Total duration of loading (without truck changing time) $4200 \mathrm{~s}$

Average duration of loading (without truck changing time) $110.53 \mathrm{~s}$

Total fuel consumption 11551

Number of cycles (tours) 38

Total of crossed route of full truck $73037 \mathrm{~m}$

Average crossed route of full truck (semi-cycle full truck) $1922.03 \mathrm{~m}$

Total of crossed route of empty truck $92923 \mathrm{~m}$ - with coming under the shovel

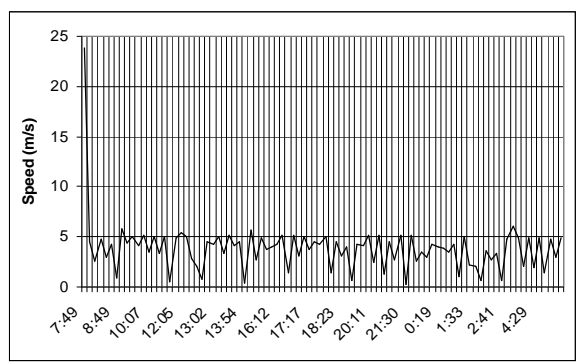

Figure 12

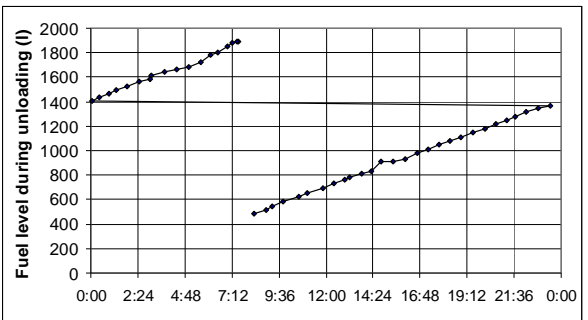

Figure 14

at the beginning of shift and coming under the shovel at the end of shift

Average crossed route of empty truck (semi-cycle empty truck) $1950.34 \mathrm{~m}$

Total driving time of full truck $15600 \mathrm{~s}$

Average driving time of full truck (semi-cycle full truck) $410.53 \mathrm{~s}$

Average driving speed of full truck $4.68 \mathrm{~m} / \mathrm{s}$

Presentation of information in the form of graphics-truck БелАЗ 10

In Figure 15, the graph shows duration of loading and in Figure 16 mass of load transported during one cycle. In Figure 17, there is a graph of crossed routes in driving of full and empty truck and in Figure18 registered speeds.

In Figures $19 \& 20$, there is a graph about changes in the level of fuel during loading and unloading of truck. 


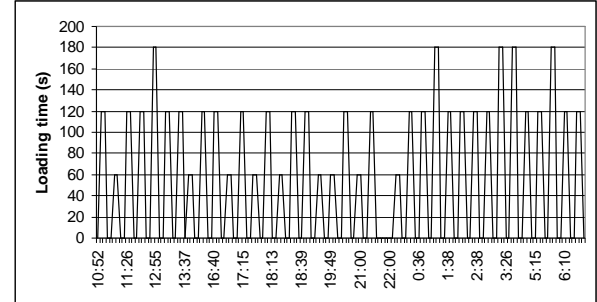

Figure 15

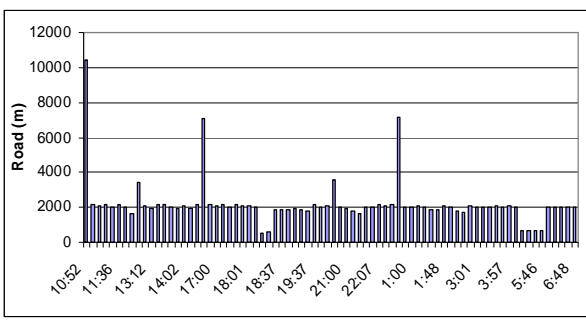

Figure 17

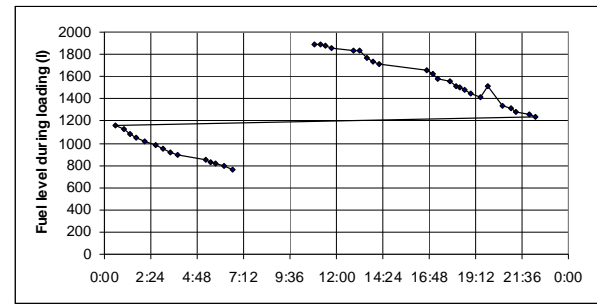

Figure 19

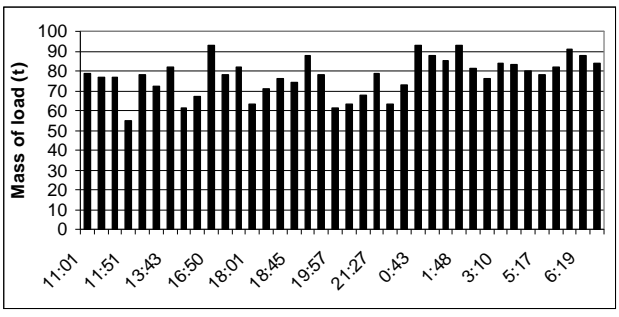

Figure 16

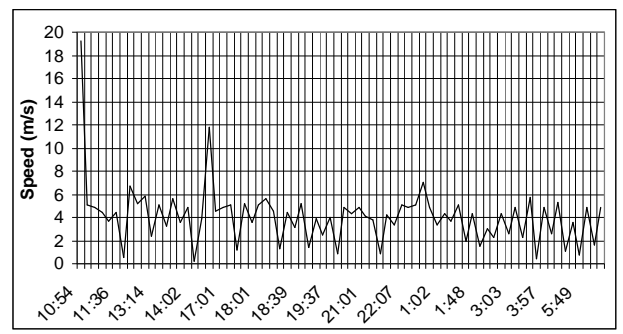

Figure 18

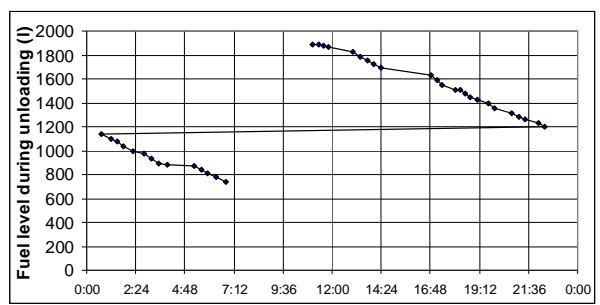

Figure 20

\section{DISCUSSION}

Analyzing the processor data of all three trucks БелА 3 in one day, it can be concluded that truck БелА 3 , in total 46 working cycles, achieved the biggest capacity (output), but truck БелАЗ 10 the smallest. In the observed day during the first shift, truck БелАЗ 10 was in service according to the reports of operational technical preparation service, and it achieved only 38 working cycles.

Although all three trucks served the same shovel, there is a significant difference in length of crossed route and dura

tion of loading. According to the records about length of crossed routes of empty truck at the beginning of shifts, the truck БелАЗ 9 was the only truck at the beginning of first shift that came from the turnover place Besin, and at the beginning of the second and third shift the turn-over performed at the shovel, it is different between the truck БелАЗ 8 and БелАЗ 10 on the other side which moved from the turn-over place Besin at the beginning of all three shifts. Figure 21 presents the shortest time of loading for БелАЗ 10, it 
is logical, because of this truck during the three shifts achieved 8 cycles fewer from the other two trucks. Minimum average

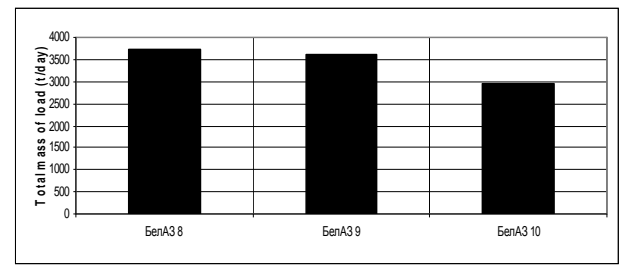

Figure 21

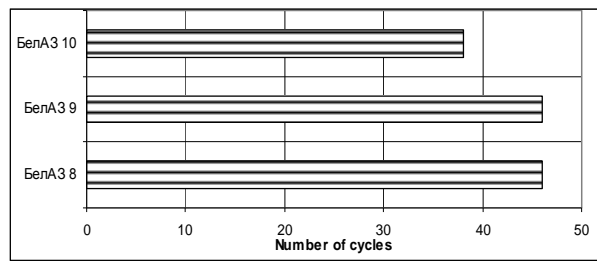

Figure 23

According to the processor data, the truck БелАЗ 11 crossed between 500 and $600 \mathrm{~km}$, while the truck БелА3 8 crossed about $170 \mathrm{~km}$ (the same shovel and the same dump). The processor is broken on the truck БелАЗ 11, so the data from this truck cannot time of loading was achieved for truck БелА3 8, and also minimum average moving speed.

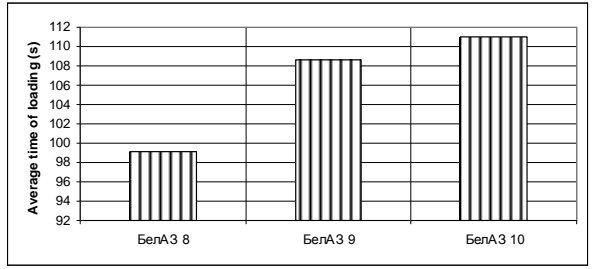

Figure 22

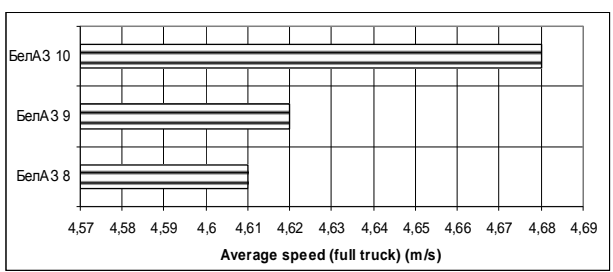

Figure 24

be used for further analysis until solving the problem.

According to the processor data, maximum amount of fuel is 1892 (1) that is registered on trucks БелА3, while in the tank can fit 1900 (1), but the average fuel consumption is shown in the next chart.

Table 1.

\begin{tabular}{|c|c|c|c|}
\hline \multirow[t]{2}{*}{ Shovel - dump } & \multicolumn{3}{|c|}{ Truck } \\
\hline & БелАЗ 8 & БелАЗ 9 & БелАЗ 10 \\
\hline \multicolumn{4}{|l|}{$\begin{array}{c}\text { Shovel ЭКГ ВИ (2) - dump of } \\
\text { the open pit Turija }\end{array}$} \\
\hline Average fuel consumption $(1 / \mathrm{km})$ & 6.76 & 7.19 & 6.9 \\
\hline Average quantity of fuel for refueling in tank (l) & 1448 & 1411 & 1154 \\
\hline \multicolumn{4}{|l|}{$\begin{array}{l}\text { Hydraulic shovel Terex RH 120E (1) - } \\
\text { dump of the open pit Turija }\end{array}$} \\
\hline Average fuel consumption $(1 / \mathrm{km}))$ & 7.48 & 7.35 & 7.50 \\
\hline Average quantity of fuel for refueling in tank (l) & 1844 & 1138 & 1437 \\
\hline \multicolumn{4}{|l|}{$\begin{array}{c}\text { Shovel Marion M } 201 \text { - dump of } \\
\text { the open pit Grivice }\end{array}$} \\
\hline Average fuel consumption $(1 / \mathrm{km})$ & 7.28 & 7.33 & 7.18 \\
\hline Average quantity of fuel for refueling in tank (l) & 1494 & 1471 & 1508 \\
\hline
\end{tabular}




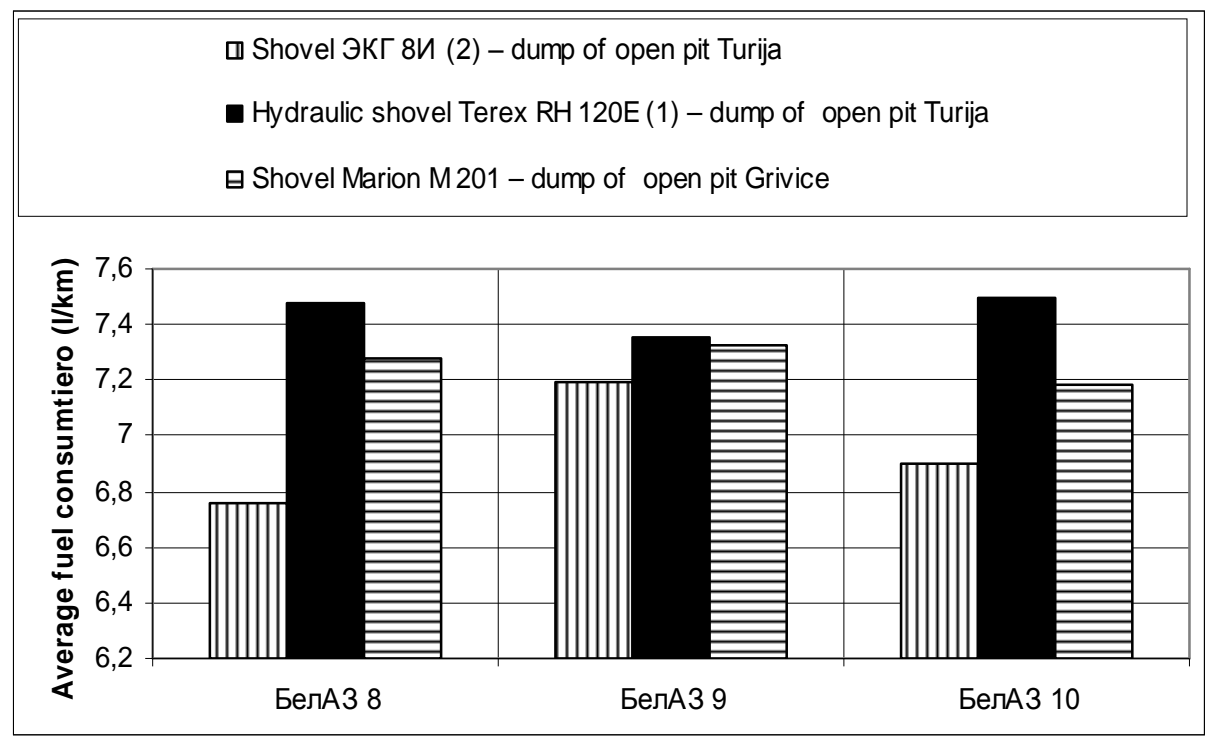

Figure 25

\section{CONCLUSION}

Total 11 trucks have processors; the processors are correct on the trucks БелА 8 , БелАЗ 9 and БелАЗ 10 and data from these processors can be used for analyses. The other trucks processors must be repaired because of using the data for analyses.

Five trucks Terex $3600 \mathrm{~B}$ and two trucks Mark 36 have not this kind of processors, so the data about working and slowdowns/cancellations cannot be analyzed in this way.

Data from the truck processors can be used for defining each working parameter of truck transport. By installation the Global Positioning System (GPS) receivers on the equipment in the Black Coal Mine „Banovici“, a new possibility of getting real and timing and spatial working insight is opened and also forming the Center for dispatchers in the Mine.

\section{REFERENCES}

[1] M. Bećić, S. Mašić, R. Čeliković: Data Basis of Monitoring Truck Transport, International Mining Conference Trends in Modern Mining, Monograph Proceedings, pp. 132-136, ISSN 15127044, Tuzla 2006;

[2] S. Mašić, M. Bećić, R. Čeliković: Defining of Individual Parameters about Truck Transport on the Basis of Data Collecting by Manual GPS Receivers, Proceedings, $38^{\text {th }}$ International October Conference on Mining and Metallurgy“, pp. 147-151, Donji Milanovac 2006;

[3] S. Hodžić, S. Mašić: Cyclical Transport, University of Tuzla, 2007;

[4] R. Borović: Truck Transport at the Open Pits, pp. 98-109, Belgrade 1995;

[5] Bauer M.: Vermessung und Ortung mit Satelliten, 2003; 
[6] Kavanagh F. B.: Geomatics, 2003;

[7] S. Mašić, M. Brčaninović, Dz. Kudumović, R. Čeliković, I. Lapandić: Analysis of Parameters about Working the Truck Transport Obtained from
Different Sources in the Brown Coal Mine "Banovici", Technics Technologies Education Management (TTEM), ISSN 1840-1503, pp. 191-196, Volume 6, No. 1, 2011. 


\begin{tabular}{ll}
\hline \hline INSTITUT ZA RUDARSTVO I METALURGIJU BOR & ISSN: 2334-8836 \\
& UDK: 622 \\
\hline \hline
\end{tabular}

Sunčica Mašić , Muhidin Brčaninović*

\title{
ANALIZA PARAMETARA RADA KAMIONA БелA3 NA POVRŠINSKIM KOPOVIMA RMU "BANOVIĆI" NA OSNOVU PODATAKA SA PROCESORA
}

\begin{abstract}
Izvod
U radu je data metodologija prikupljanja i obrade podataka iz sistema za kontrolu tereta i goriva CKЗиT, a koji se nalaze na kamionima БелA3 75131 koje posjeduje Rudnik mrkog uglja (RMU) „Banovići “ $u$ Banovićima. Takođe, predstavljena je i metodologija prikaza ostvarenih parametara rada.

Ovim kamionima vrši se transportovanje i uglja $i$ otkrivke (jalovine) na površinskim kopovima navedenog rudnika. Ukupno jedanaest kamiona posjeduju procesore. Obradom podataka mogu se izvesti zaključci o vremenima rada, dužinama pređenih puteva, količini prevezenog tereta, ostvarenim ciklusima itd.
\end{abstract}

Ključne riječi: površinski kop, kamion, БелA3, RMU „Banovići“, procesor

\section{UVOD}

Proizvodnja (otkrivka i dobivanje uglja) na površinskim kopovima Rudnika mrkog uglja „Banovići“ d.d. Banovići ostvaruje se diskontinuiranom tehnologijom sa primjenom klasičnog cikličnog utovarno-transportnog kompleksa bager-kamion.

Sistem površinske eksploatacije je redoslijed izvođenja radova na otkopavanju, transportu i odlaganju otkrivke, dobivanju i drugim (pomoćnim) procesima, kojim se obezbjeđuje projektovani (planirani) kapacitet površinskog kopa. Na površinskim kopovima RMU „Banovići“ („Grivice“ i „Turija“) primjenjuje se uzdužni jednokrilni sistem eksploatacije sa produbljavanjem po krovinskom kontaktu rudnog tijela (ugljenog sloja) i transportom otkrivke na vanjska odlagališta.

Proizvodni proces otkrivke i uglja sastoji se od slijedećih radnih procesa: bušenje i miniranje (priprema stijene za kopanje i utovar), kopanje i utovar (bagerovanje), transport, odlaganje otkrivke i deponovanje uglja (po potrebi).

Nakon utovara uglja u kamione vrši se transport istog sa etaže i istovar u drobilično postrojenje. Transport uglja od drobiličnog postrojenja do pretovarnog bunkera na željezničkoj stanici „Draganja“ vrši se sistemom transportera sa gumenom trakom, a dalje željeznicom do separacije, dok se na površinskom kopu „Turija“ transport uglja u pretovarni bunker vrši kamionima. Transport otkrivke obavlja se direktnim prevozom kamionima sa etaže na površinskom kopu do etaže na odlagalištu.

Površinski kopovi su međusobno povezani veznim transportnim putevima koji služe za prelazak kamiona i druge mehanizacije sa jednog na drugi površinski kop, kao i do servisnog kompleksa „Bešin“ radi preventivnog održavanja i opravki. Radovi na otkrivci se izvode tako što se nakon bušenja i miniranja otkrivka bagerima utovara $u$

${ }^{*}$ RGGF Tuzla BiH 
kamione. Kopanje i utovar otkrivke vrši se bagerima kašikarima i hidrauličnim bagerima uz prethodno miniranje stijenske mase iznad bagerskog nivoa. Kamionima se otkrivka sa etaže na površinskom kopu transportnim putevima prevozi do etaže na odlagalištu. Na odlagalištu kamion odlagališnim putem odlazi do odlagališne etaže na kojoj vrši odlaganje otkrivke. Svi transportni putevi su izrađeni od otkrivke i nasuti čvrstim i postojanim laporcima.

\section{PODACI DOBIVENI SA PROCE- SORA NA KAMIONIMA БеЛАЗ}

RMU „Banovići“ posjeduje 11 kamiona БелАЗ 75131 na kojima se nalaze procesori odnosno sistem za kontrolu tereta i goriva СКЗиТ.

Ovaj sistem pored praćenja prevezenog tereta i potrošnje goriva daje podatke i o vremenima utovara i istovara kao i dužinama pređenih puteva punih i praznih kamiona.

Sistem kontrole tereta i goriva СКЗиТ čine slijedeći elementi: kontroler, panel upravljanja i indikacije, davači pritiska na amortizerima, senzor nivoa goriva u rezervoaru, inklinometar i semafor za signalizaciju količine tereta.

Na slici 1 prikazan je modul sa panelom sistema СКЗиТ. Podaci sa procesora na kamionima БелА3 dobijaju se u formi prikazanoj na slici 2.

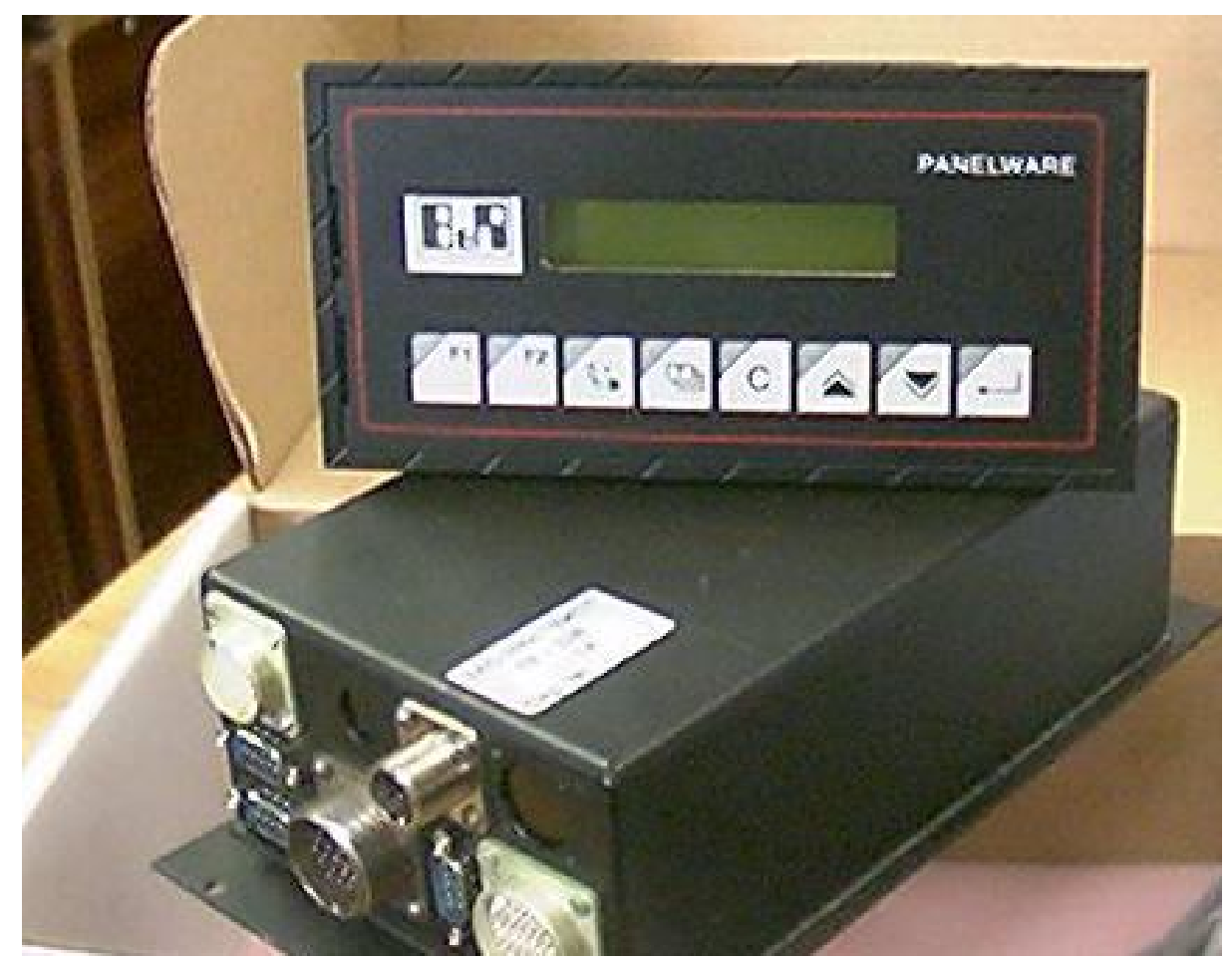

Sl. 1. Modul tereta sa panelom 


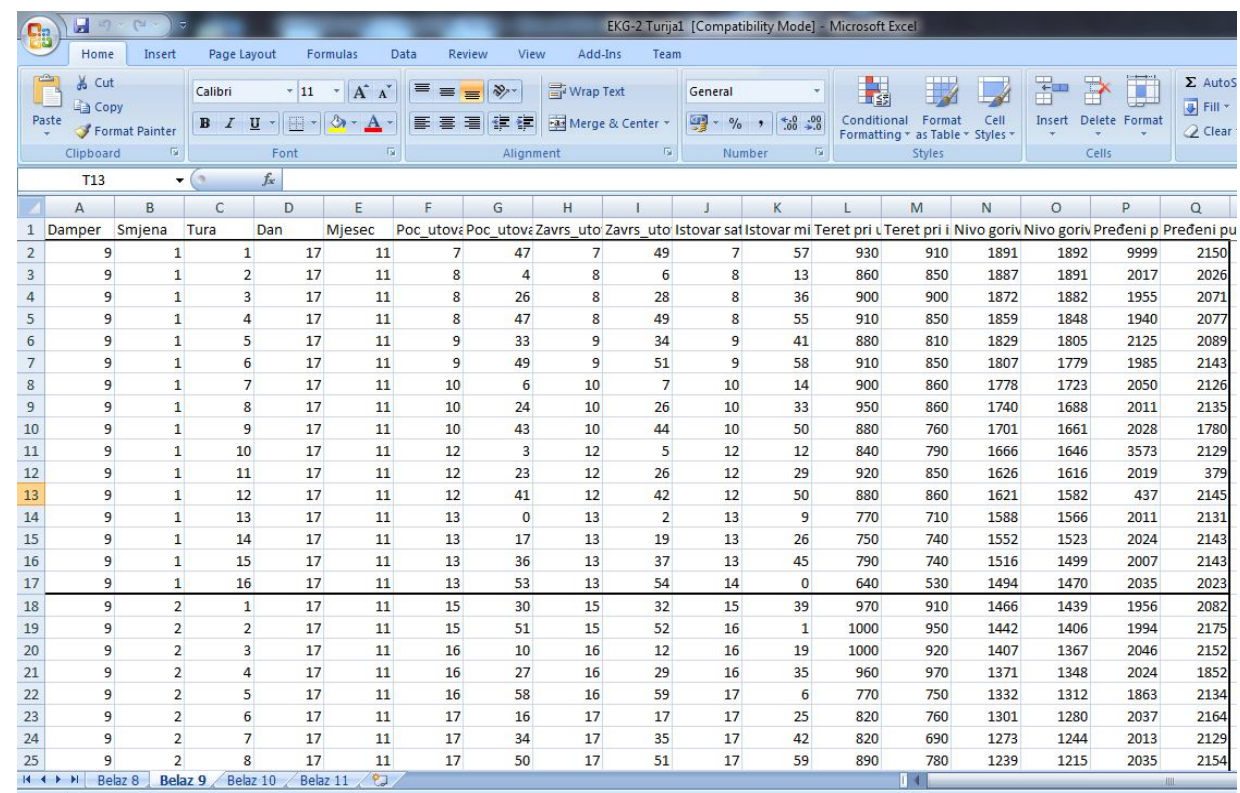

Sl. 2.

Za jednu smjenu dobije se oko 255 podataka koji se mogu iskoristiti za pojedine transformacije, a kasnije za analize. Podatke sa procesora kamiona neophodno je prethodno pripremiti za analizu. Podaci su u takvom obliku da je potrebno izvršiti transformaciju podataka za vrijeme jer su po kolonama razvrstani po satima i minutama (slika 2). Ove podatke da bi se dijagramski predstavili neophodno je transformisati u podatke oblika TIME (0:00:00). U Microsoft Excel-u potrebno je izvršiti ubacivanje novih kolona da bi se dobili podaci oblika TIME (0:00:00) i vrijeme izraženo u sekundama. U prikazanoj datoteci sa procesora može se primjetiti da se ne evidentira vrijeme koje pokazuje i sekunde, za razliku od podataka koji bi se dobili na osnovu praćenja kamiona koji bi imali ugrađene GPS prijemnike. U dvije zasebne kolone dati su registrovani podaci o masi tereta neposredno poslije utovara $\mathrm{i}$ pri istovaru uvećane 10 puta. Uglavnom, podaci o masi tereta neposredno po završetku utovara pokazuju znatne razlike u odnosu na registrovane podatke pri istovaru. Ove dvije vrijednosti se razlikuju zbog toga što senzor prilikom utovara registruje veću vrijednost tereta, jer je teret neravnomjerno raspoređen u sanduku kamiona. Prilikom transporta od mjesta utovara do mjesta istovara dolazi do ravnomjernije raspodjele tereta $\mathrm{i}$ pri tome registrovana masa tereta pri istovaru je mjerodavna za dalju analizu. Podaci o vremenima vožnje opterećenog kamiona (pun kamion) mogu se dobiti iz razlike registrovanog vremena istovara $i$ vremena završetka utovara. U datoteci su prikazane vrijednosti pređenih puteva opterećenog (pun) i neopterećenog (prazan) kamiona. Dijeleći vrijednosti dužina pređenih puteva sa vremenima vožnje opterećenog (punog) kamiona mogu se dobiti brzine vožnje opterećenog (punog) kamiona. Ako odredimo razliku registrovanih vremena početka utovara $\mathrm{i}$ vremena prethodnog istovara dobijaju se vremena vožnje praznog (neopterećenog) kamiona koja su puno veća od vremena vožnje punog kamiona, te su dobijene brzine vožnje praznog kamiona male u odnosu na brzine punog kamiona. Dužine pređenih puteva neopterećenog 
(praznog) kamiona u sebi sadržavaju i dužine vezane za manevrisanje pri utovaru, tako da nisu adekvatne za određivanje brzina vožnje istog.

\section{OSTVARENI PARAMETRI RADA КАMIONA БелАЗ 8, БелАЗ 9 i БелАЗ 10}

Analizom podataka sa procesora moguće je prikazati ostvarene rezultata rada kamiona za svaku smjenu pojedinačno. Dnevni izvještaji o radu tri kamiona koji su razmatrani prikazani su u narednom tekstu.

Površinski kop Turija

Bager kašikar ЭКГ 8И (2)

Каmion БелАЗ 75131 (8)

Odlagalište površinskog kopa Turija

\section{Dnevni izvještaj}

Ukupno prevezeno tereta $3.726(\mathrm{t})$

Prosječna vrijednost prevezenog tereta $81(\mathrm{t})$ po ciklusu.

Ukupno vrijeme trajanja utovara (bez vremena zamjene kamiona) 4.560 (s).

Prosječno vrijeme trajanja utovara (bez vremena zamjene kamiona) 99,13 (s).

Ukupna potrošnja goriva 1.408 (l).

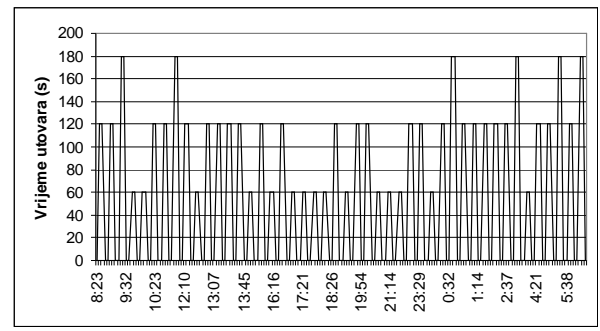

Sl. 3.

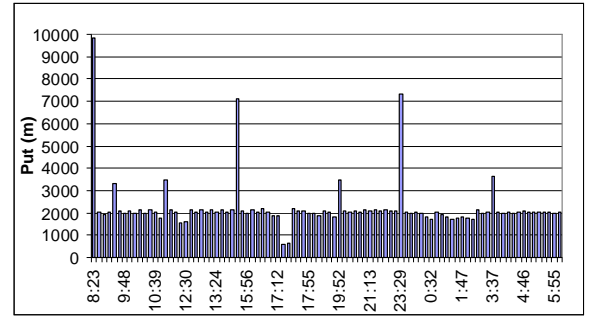

Sl. 5.
Broj ciklusa (tura) 46.

Ukupno pređeni put kamiona pod teretom (pun kamion) 91.720 (m).

Prosječno pređeni put kamiona pod teretom - (poluciklus pun kamion) 1.993,91 (m)

Ukupno pređeni put kamiona bez tereta (prazan kamion) 101.196 (m) - sa dolaskom pod bager na početku smjene i dolaskom pod bager na kraju smjene.

Prosječno pređeni put kamiona bez tereta - (poluciklus prazan kamion) 2.026,6 (m).

Ukupno vrijeme vožnje kamiona pod teretom (pun kamion) 19.920 (s).

Prosječno vrijeme vožnje kamiona pod teretom (poluciklus pun kamion) 433,04 (s).

Prosječna brzina vožnje kamiona pod teretom (pun kamion) 4,60 (m/s).

\section{Predstavljanje informacija $\boldsymbol{u}$ vidu grafika - kamion БелА 8}

Na slici 3 dat je prikaz vremena trajanja utovara, a na slici 4 masa tereta prevezena $u$ toku jednog ciklusa. Na slici 5 dat je prikaz pređenih puteva pri kretanju punog i praznog kamiona, a na slici 6 registrovane brzine.

$\mathrm{Na}$ slici 7 i 8 dat je prikaz promjene nivoa goriva pri utovaru $\mathrm{i}$ istovaru kamiona.

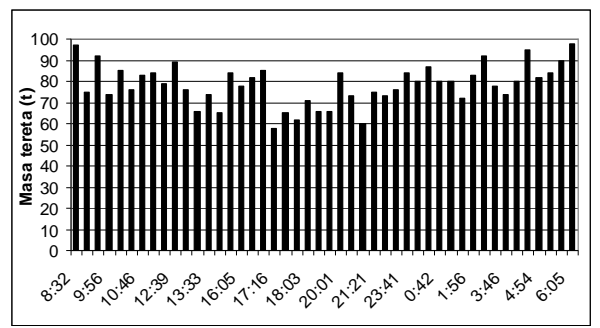

Sl. 4.

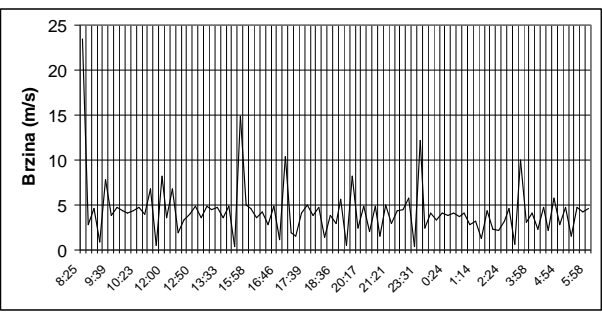

Sl. 6. 


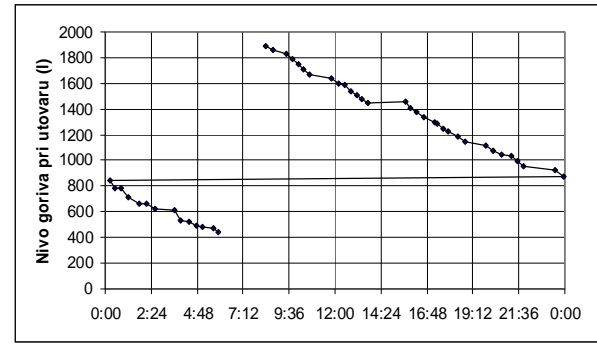

Sl. 7.

Površinski kop Turija

Bager kašikar ЭКГ $8 И$ (2)

Каmion БелАЗ 75131 (9)

Odlagalište površinskog kopa Turija

\section{Dnevni izvještaj}

Ukupno prevezeno tereta $3.612(\mathrm{t})$.

Prosječna vrijednost prevezenog tereta $78,52(\mathrm{t})$ po ciklusu.

Ukupno vrijeme trajanja utovara (bez vremena zamjene kamiona) 4.980 (s).

Prosječno vrijeme trajanja utovara (bez vremena zamjene kamiona) 108,26 (s).

Ukupna potrošnja goriva 1.454 (1).

Broj ciklusa (tura) 46.

Ukupno pređeni put kamiona pod teretom (pun kamion) 91.885 (m).

Prosječno pređeni put kamiona pod teretom-(poluciklus pun kamion) 1997,50 (m)

Ukupno pređeni put kamiona bez tereta (prazan kamion) 113481 (m) - sa dolaskom

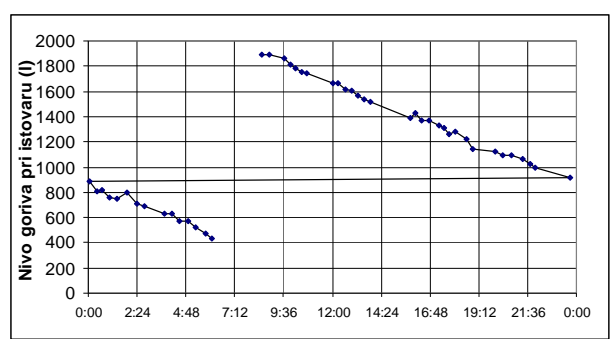

Sl. 8.

pod bager na početku smjene i dolaskom pod bager na kraju smjene.

Prosječno pređeni put kamiona bez tereta - (poluciklus prazan kamion) 2.074,209 (m).

Ukupno vrijeme vožnje kamiona pod teretom (pun kamion) 19.860 (s)

Prosječno vrijeme vožnje kamiona pod teretom (poluciklus pun kamion) 431,74 (s)

Prosječna brzina vožnje kamiona pod teretom (pun kamion) 4,63 (m/s)

\section{Predstavljanje informacija u vidu grafika-}

\section{kamion БелАЗ 9}

Na slici 9 dat je prikaz vremena trajanja utovara, a na slici 10 masa tereta prevezena u toku jednog ciklusa. Na slici 11 dat je prikaz pređenih puteva pri kretanju punog i praznog kamiona, a na slici 12 registrovane brzine.

Na slici 13 i 14 dat je prikaz promjene nivoa goriva pri utovaru $\mathrm{i}$ istovaru kamiona.

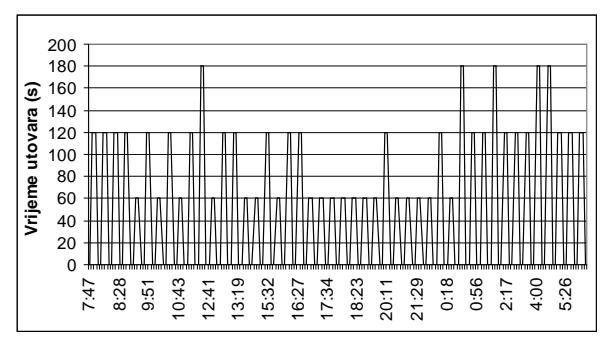

Sl. 9.

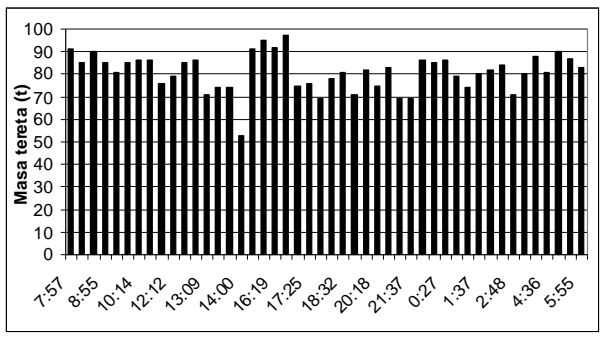

Sl. 10. 


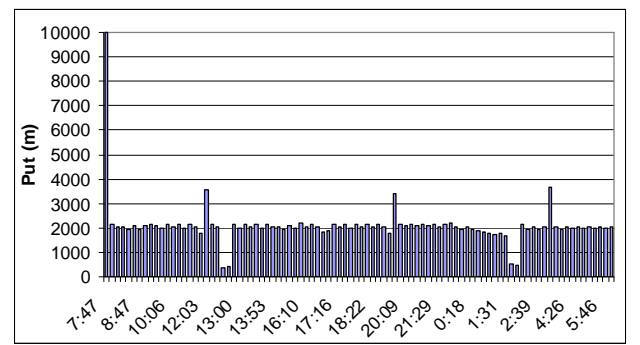

Sl. 11.

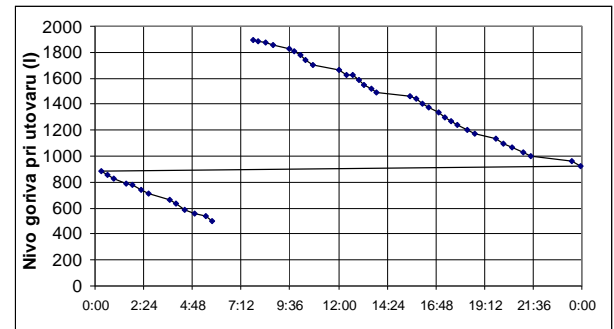

Sl. 13.

Površinski kop Turija

Bager kašikar ЭКГ 8И (2)

Каmion БелАЗ 75131 (10)

Odlagalište površinskog kopa Turija

\section{Dnevni izvještaj}

Ukupno prevezeno tereta $2.944(\mathrm{t})$.

Prosječna vrijednost prevezenog tereta $77,47(\mathrm{t})$ po ciklusu.

Ukupno vrijeme trajanja utovara (bez vremena zamjene kamiona) 4.200 (s).

Prosječno vrijeme trajanja utovara (bez vremena zamjene kamiona) 110,53 (s).

Ukupna potrošnja goriva 1.155 (l).

Broj ciklusa (tura) 38 .

Ukupno pređeni put kamiona pod teretom (pun kamion) 73.037 (m).

Prosječno pređeni put kamiona pod teretom - (poluciklus pun kamion) 1922,03 (m)

Ukupno pređeni put kamiona bez tereta (prazan kamion) 92.923 (m) - sa dolaskom

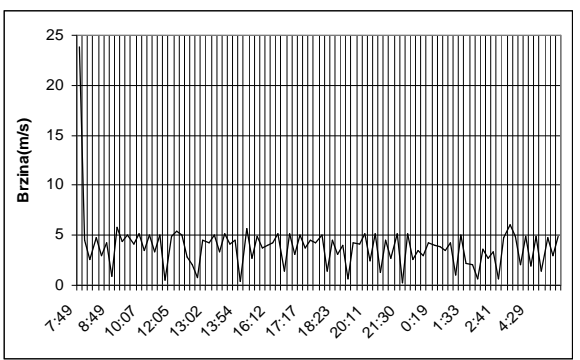

Sl. 12.

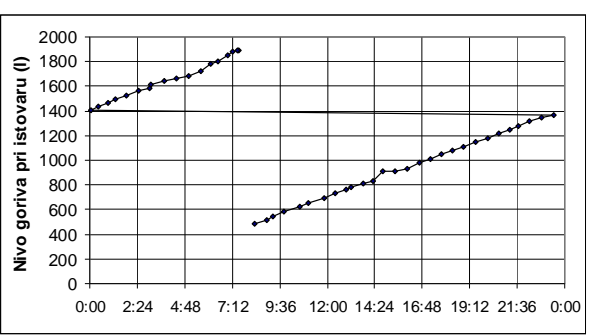

Sl. 14.

pod bager na početku smjene i dolaskom pod bager na kraju smjene.

Prosječno pređeni put kamiona bez tere-ta - (poluciklus prazan kamion) 1.950,34 (m).

Ukupno vrijeme vožnje kamiona pod teretom (pun kamion) 15.600 (s).

Prosječno vrijeme vožnje kamiona pod teretom (poluciklus pun kamion) 410,53 (s).

Prosječna brzina vožnje kamiona pod teretom (pun kamion) 4,68 (m/s).

\section{Predstavljanje informacija $\boldsymbol{u}$ vidu grafika-kamion БелАЗ 10}

$\mathrm{Na}$ slici 15 dat je prikaz vremena trajanja utovara, a na slici 16 masa tereta prevezena u toku jednog ciklusa. Na slici 17 dat je prikaz pređenih puteva pri kretanju punog i praznog kamiona, a na slici 18 registrovane brzine.

Na slici 19 i 20 dat je prikaz promjene nivoa goriva pri utovaru $\mathrm{i}$ istovaru kamiona. 


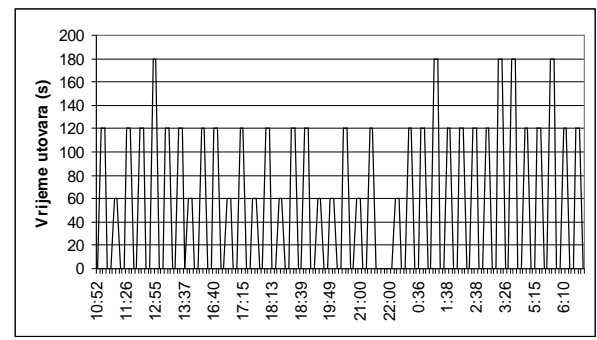

Sl. 15.

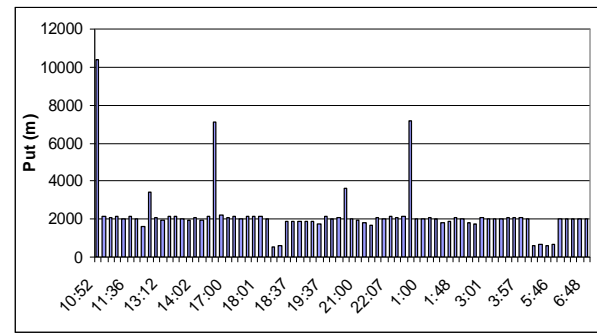

Sl. 17.

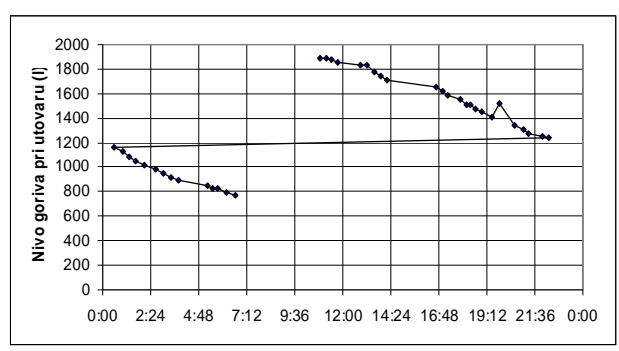

Sl. 19.

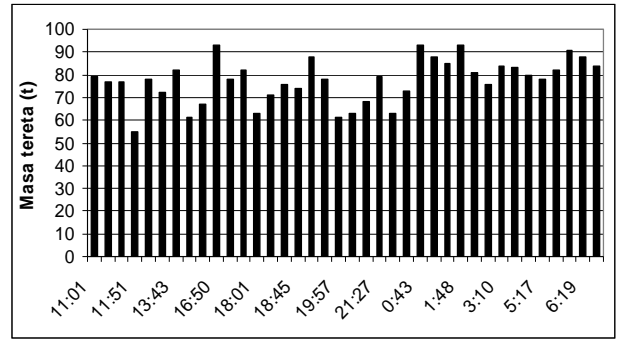

Sl. 16.

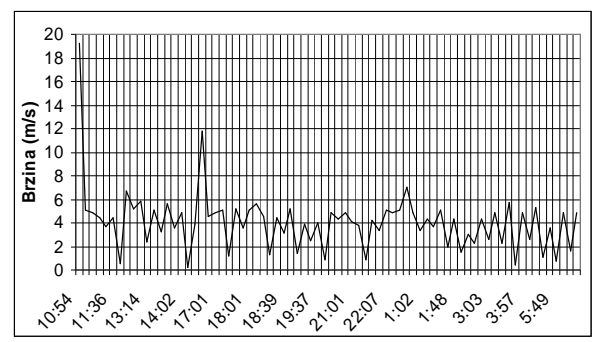

Sl. 18.

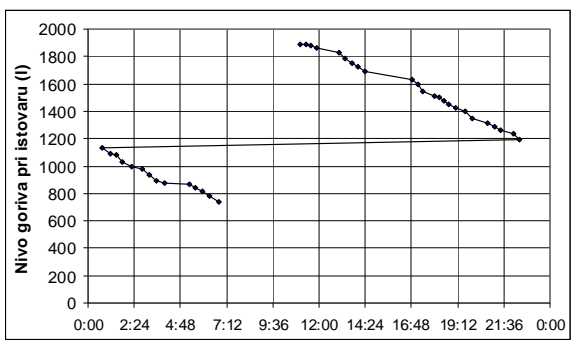

SI. 20.

\section{DISKUSIJA}

Analizirajući podatke sa procesora sva tri kamiona БелА3 75131 za jedan dan može se zaključiti da je kamion БелА3 8 u ukupno 46 ciklusa rada ostvario najveći kapacitet, a kamion БелА3 10 najmanji. Каmion БелАЗ 10 posmatranog dana u toku prve smjene nalazio se na servisu prema evidenciji službe operativno tehničke pripreme, te je ostvario samo 38 ciklusa rada. Iako su sva tri kamiona opsluživala isti bager evidentna je razlika u dužinama pređenih puteva i vremenu trajanja utovara. Prema evidenciji o dužinama pređenih puteva praz-

nog kamiona na početku smjena, kamion БелАЗ 9 je samo na početku prve smjene imao dolazak sa primopredajnog mjesta Bešin, a na početku druge i treće smjene primopredaja je izvršena kod bagera, za razliku od kamiona БелА3 8 і БелА3 10 koji su na početku sve tri smjene dolazili sa primopredajnog mjesta Bešin.

Sa slike 21 može se uočiti da je ukupno vrijeme utovara najmanje za БелАЗ 10, što je i logično, jer je ovaj kamion u toku tri smjene ostvario 8 ciklusa manje 
od ostala dva kamiona. Najmanje prosječno vrijeme utovara je ostvareno za kamion БелА3 8, kao i najmanja prosječna brzina kretanja.

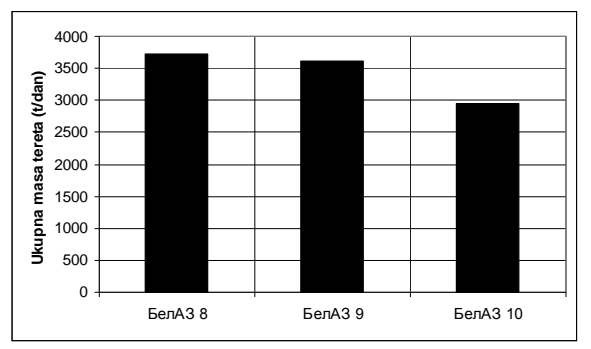

Sl. 21.

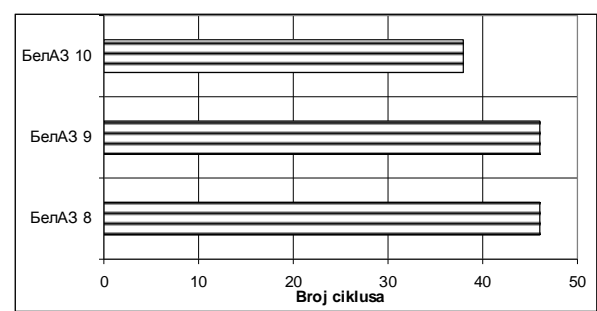

Sl. 23.

Prema podacima sa procesora kamiona БелАЗ 11 u toku dana on pređe 500 do 600 km, dok БелАЗ 8 pređe oko 170 km (isti bager isto odlagalište). $\mathrm{Na}$ kamionu БелАЗ 11 procesor nije ispravan tako da se podaci sa ovog kamiona ne mogu iskoristiti za dalju analizu dok se ne otkloni kvar.

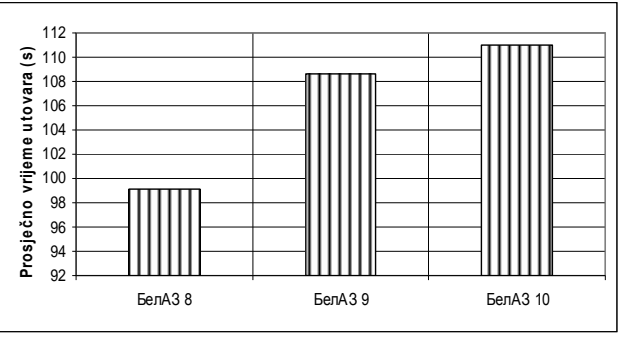

Sl. 22.

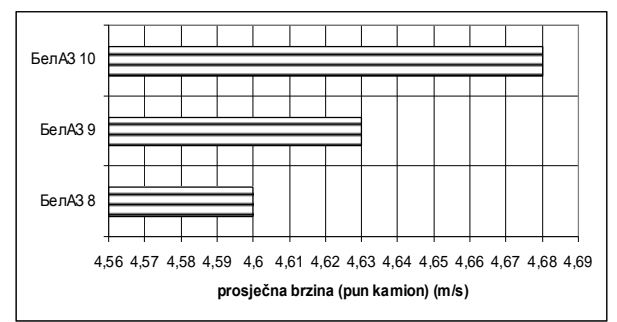

Sl. 24.

Prema podacima sa procesora maksimalna količina goriva koja se registruje u kamionima БелАЗ je 1.892 (1) dok u rezervoar može stati 1.900 (1), a prosječna potrošnja goriva prikazana je u sljedećem grafikonu.

Tabela 1.

\begin{tabular}{|c|c|c|c|}
\hline \multirow{2}{*}{ Bager - odlagalište } & \multicolumn{3}{|c|}{ Kamion } \\
\hline & БелАЗ 8 & БелАЗ 9 & БелАЗ 10 \\
\hline \multicolumn{4}{|l|}{$\begin{array}{c}\text { Bager kašikar ЭКГ 8И (2) - } \\
\text { odlagalište površinskog kopa Turija }\end{array}$} \\
\hline Prosječna potrošnja goriva $(1 / \mathrm{km})$ & 6,76 & 7,19 & 6,9 \\
\hline $\begin{array}{l}\text { Prosječna količina goriva koja se dopunjava u } \\
\text { rezervoar (l) }\end{array}$ & 1448 & 1411 & 1154 \\
\hline \multicolumn{4}{|l|}{$\begin{array}{c}\text { Hidraulični bager Terex RH 120E (1) - } \\
\text { odlagalište površinskog kopa Turija }\end{array}$} \\
\hline Prosječna potrošnja goriva $(\mathrm{l} / \mathrm{km})$ & 7,48 & 7,35 & 7,50 \\
\hline $\begin{array}{l}\text { Prosječna količina goriva koja se dopunjava u } \\
\text { rezervoar (l) }\end{array}$ & 1844 & 1138 & 1437 \\
\hline \multicolumn{4}{|l|}{$\begin{array}{c}\text { Bager kašikar Marion M } 201 \text { - odlagalište } \\
\text { površinskog kopa Grivice }\end{array}$} \\
\hline Prosječna potrošnja goriva $(1 / \mathrm{km})$ & 7,28 & 7,33 & 7,18 \\
\hline $\begin{array}{l}\text { Prosječna količina goriva koja se dopunjava u } \\
\text { rezervoar (l) }\end{array}$ & 1494 & 1471 & 1508 \\
\hline
\end{tabular}




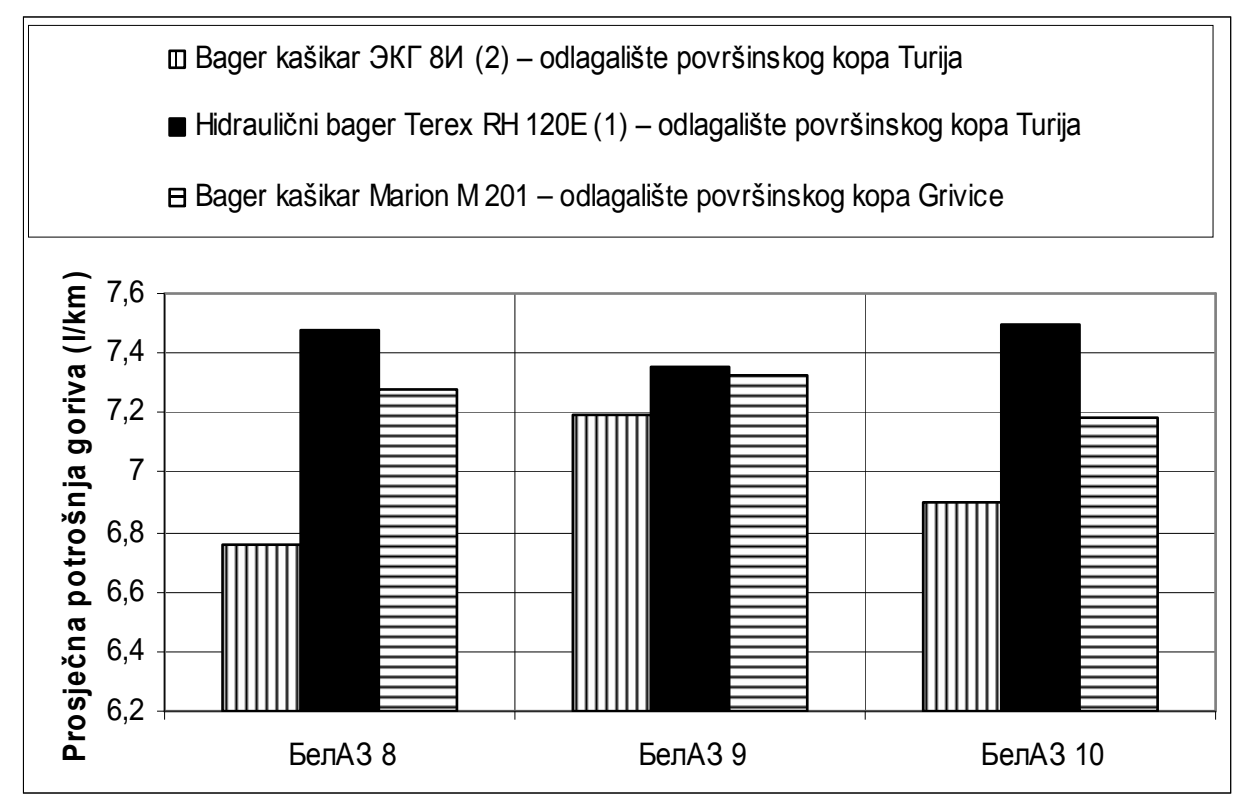

Sl. 25.

\section{ZAKLJUČAK}

Ukupno jedanaest kamiona posjeduje procesore, od kojih su na kamionima БелАЗ 8, БелАЗ 9 і БелА3 10 procesori u ispravnom stanju, te se podaci sa ovih procesora mogu koristiti za analize. Kod ostalih kamiona potrebno je izvršiti popravku procesora da bi podaci o radu bili dostupni za analize.

Pet kamiona Terex 3600 B i dva kamiona tipa Mark 36 ne posjeduju ovakve procesore, te se podaci o radu i zastojima /otkazima ne mogu analizirati na ovaj način.

Podaci sa procesora kamiona mogu se iskoristiti za određivanje pojedinih parametara rada kamionskog transporta. Ugradnjom Global Positioning System (GPS) prijemnika na opremu kojom raspolaže RMU „Banovići“ otvara se mogućnost dobijanja stvarne i vremenske i prostorne slika rada, kao i formiranje dispečerskog centra u rudniku.

\section{LITERATURA}

[1] M. Bećić, S. Mašić, R. Čeliković: Baza podataka praćenja kamionskog transporta, „Međunarodna naučno-stručna konferencija TIMC 05/06 Trendovi u savremenom rudarstvu“, Monografija zbornika radova, ISSN 1512-7044, str. 132-136, Tuzla 2006.

[2] S. Mašić, M. Bećić, R. Čeliković,: Određivanje pojedinih parametara kamionskog transporta na osnovu podataka prikupljenih ručnim GPS prijemnikom, Zbornik radova ,38th International October Conference on Mining and Metallurgy“, str. 147-151, Donji Milanovac 2006.

[3] S. Hodžić, S. Mašić: Ciklični transport, Univerzitet u Tuzli, 2007.

[4] R. Borović: Kamionski transport na površinskim kopovima, str. 98-109, Beograd 1995. 
[5] Bauer M.: Vermessung und Ortung mit Satelliten, 2003.

[6] Kavanagh F. B.: Geomatics, 2003.

[7] S. Mašić, M. Brčaninović, Dž. Kudumović, R. Čeliković, I. Lapandić: Analysis of parameters about working the truck transport obtained from different sources in Black Coal Mine ,Banovici“, Technics Technologies Education Management (TTEM), ISSN 18401503, pp. 191-196, Volume 6 Number 1, 2011. 